\title{
Interaction of corticosteroids and catecholamines in the treatment of asthma
}

\author{
G IL L A N M. SHENFIELD, MARGARET E. HODSON, \\ S. W. CLARKE, and J.W. PA TER S N \\ Asthma Research Council Clinical Pharmacology Unit, Department of Medicine, \\ Cardiothoracic Institute, and Brompton Hospital, London SW3 $6 H^{P}$
}

\begin{abstract}
Shenfield, Gillian M., Hodson, Margaret E., Clarke, S. W., and Paterson, J. W. (1975). Thorax, 30, 430-435. Interaction of corticosteroids and catecholamines in the treatment of asthma. Twelve patients with airways obstruction (due to asthma and/or chronic bronchitis) were given a trial of prednisone therapy to assess reversibility. Six asthmatic patients responded well but no predictive criteria were found. In three patients improvement in forced expiratory volume in 1 second $\left(\mathrm{FEV}_{1}\right)$ was detectable at 6 hours but not at 3 hours. One patient took 36 hours to show any sign of improvement. None of the patients who improved reached their peak $\mathrm{FEV}_{1}$ before six days treatment with prednisone, which suggests that a 'trial of steroids' should last for at least one week.

Potentiation, as measured by either a greater peak rise or a more sustained increase in $\mathrm{FEV}_{1}$ after isoprenaline, was observed in five of the six asthmatic patients responding to steroids.

It is concluded that potentiation of catecholamines is one of the mechanisms by which corticosteroids may act in asthma.
\end{abstract}

Corticosteroids have been used to treat asthma since Carryer et al. (1950) showed that intramuscular cortisone was effective in three patients. Their mode of action is still not known. Several theories have been proposed and have been reviewed by Aviado and Carrillo (1970). Their actions at cellular level have been discussed by Baxter and Forsham (1972), and Feldman, Funder, and Edelman (1972). Schayer (1964) proposed a single action for all glucocorticoids but it is more probable that they produce their therapeutic effect by several different mechanisms. One of these may be the potentiation of the actions of both endogenous and exogenous catecholamines. Kennedy (1961) published records of a series of asthmatic patients, three of whom showed a clear increase in their response to isoprenaline when they were on corticosteroids. Franklin et al. (1958) studied 58 patients with 'obstructive pulmonary emphysema' and found that, in general, the increase in vital capacity after inhaled isoprenaline was greater when the patients were on corticosteroids. However, not all their patients showed this pattern of response. Lukas (1951) also described one patient who showed such potentiation on ACTH. Bass (1972) claimed that responses to isoprenaline were greater without than with? corticosteroids.

In view of this conflicting evidence we decided to record the response to isoprenaline in a group $x$ of patients receiving a trial of steroid therapy.

\section{METHODS}

Fourteen patients were studied initially but two were withdrawn from the series, one because of deterioration necessitating treatment with intra- $\frac{D}{0}$ venous hydrocortisone, and the other because of poor reproducibility of pulmonary function tests. N Details of the 12 remaining patients are given in Table I. Patients were considered to have extrinsic asthma if they had positive skin tests to more than one common allergen. All were admitted with deteriorating airways obstruction fore a trial of corticosteroid treatment. None was ill enough to need intravenous hydrocortisone. Before starting the study it was established that $\frac{7}{0}$ the patients knew how to use a pressurized $\frac{}{\mathrm{D}}$ aerosol and a dry spirometer (Vitalograph). All of $\frac{\rho}{\Phi}$ them were on oral bronchodilator drugs, and $\stackrel{\Phi}{\varrho}$ these were taken at $6 \mathrm{am}$ and after the lunchtime 
T A B L E I

\begin{tabular}{|c|c|c|c|c|c|}
\hline Patient & Age and Sex & Diagnosis & $\begin{array}{c}\text { Length of History } \\
(y r)\end{array}$ & Previous Steroids & Other Treatment \\
\hline AC & 57 & Intrinsic & 2 & No & Oral salbutamol \\
\hline MB & 36 & Extrinsic & 27 & No & Oral orciprenaline \\
\hline BB & 47 & $\begin{array}{l}\text { asthma } \\
\text { Intrinsic }\end{array}$ & 24 & On $5 \mathrm{mg}$ bd & Oral salbutamol \\
\hline $\mathbf{V M}$ & $\begin{array}{l}F \\
52\end{array}$ & asthma & 12 & $\begin{array}{c}15 \mathrm{yr} \\
\text { No }\end{array}$ & Oral salbutamol \\
\hline MaB & 51 & Intrinsic & 2 & No & Oral Franol \\
\hline MN & 48 & Intrinsic & $0 \cdot 25$ & No & Oral salbutamol \\
\hline DW & 59 & Intrinsic & $1 \cdot 5$ & On $5 \mathrm{mg}$ bd & Oral salbutamol \\
\hline JA & 67 & Bronchitis & 15 & Short course & Amesec \\
\hline $\mathrm{CC}$ & $\begin{array}{l}17 \\
\mathbf{M}\end{array}$ & $\begin{array}{l}\text { Bronchitis } \\
\text { Emphysema }\end{array}$ & 14 & $\begin{array}{l}1 \text { yr berore } \\
\text { No }\end{array}$ & $\begin{array}{l}\text { Oral salbutamol } \\
\text { Frusemide } \\
\text { Oxytetracycline }\end{array}$ \\
\hline FD & $\begin{array}{l}70 \\
\mathbf{M}\end{array}$ & $\begin{array}{l}\text { Extrinsic } \\
\text { asthma } \\
\text { Bronchitis }\end{array}$ & 65 & No & $\begin{array}{l}\text { Oxytetracycline } \\
\text { Oral salbutamol } \\
\text { Frusemide } \\
\text { Oxytetracycline }\end{array}$ \\
\hline $\mathbf{B H}$ & $\begin{array}{l}67 \\
\mathbf{M}\end{array}$ & Bronchitis & 15 & No & $\begin{array}{l}\text { Oral salbutamol } \\
\text { Frusemide }\end{array}$ \\
\hline DB & $\stackrel{66}{F}$ & $\begin{array}{l}\text { Intrinsic } \\
\text { asthma } \\
\text { Bronchitis }\end{array}$ & 12 & No & Oral salbutamol \\
\hline
\end{tabular}

and evening measurements had been made. No aerosol bronchodilators were allowed at times other than the study sessions. When practical, baseline measurements were made throughout one day before starting prednisone but in some patients only one or two baseline sessions were possible. The dose of prednisone was started at $40 \mathrm{mg}$ above the previous dose so that most patients received $40 \mathrm{mg}$, but patients $\mathrm{BB}$ and DW had $50 \mathrm{mg}$ a day. This was given in four divided doses: at $6 \mathrm{am}$, after the lunchtime and evening measurements, and at $10 \mathrm{pm}$.

The patients were studied three times a day: between 8.30 and $9.30 \mathrm{am}$, between 12.30 and $1.30 \mathrm{pm}$, and between 5 and $6 \mathrm{pm}$. In each test period, baseline measurements were made of pulse rate, forced expiratory volume in 1 second $\left(F E V_{1}\right)$, and forced vital capacity (FVC). The patients then took two puffs from an isoprenaline inhaler (Medihaler Iso containing $100 \mu \mathrm{g}$ isoprenaline sulphate per puff). At intervals of 5,15 , and 30 minutes after the inhalation measurements of pulse rate, $\mathrm{FEV}_{1}$ and FVC were repeated. On every occasion the patients blew into the spirometer three times, and the best of the three readings were taken, as recommended by Pemberton and Flanagan (1956) and Freedman and Prowse (1966). For each individual patient, the same Medihaler was used throughout the studies, and all observations were made by the same two observirs (MEH and GMS). The measurements were repeated on seven consecutive days after the start of prednisone treatment.

\section{RESULTS}

Response to prednisone was judged by the patient's subjective feeling and an improvement in both exercise tolerance and pulmonary function tests over the seven days (Table II). Using these criteria, the first six patients were judged to have improved on prednisone; the other six patients were considered as 'failures', and the prednisone was stopped. Results were analysed in terms of $\mathrm{FEV}_{1}$, since FVC proved to be more effortdependent and less reproducible. This is shown in Fig. 1 (patient $\mathrm{CC}-\mathrm{a}$ failure), which also illustrates the reproducibility of the $\mathrm{FEV}_{1}$ response. On each occasion the baseline $\mathrm{FEV}_{1}$ and FVC and the level reached 5 minutes after two puffs of isoprenaline are shown. It can be seen that, in terms of $\mathrm{FEV}_{1}$, there was no improvement on prednisone either before or after isoprenaline.

In Table II the baseline FEV ${ }_{1}$ is the best of three obtained at the first study. The improvement in $\mathrm{FEV}_{1}$ expressed as a percentage of the predicted $\mathrm{FEV}_{1}$, is striking in the first six patients (Table II). For these 'responding' patients the best $\mathrm{FEV}_{1}$ was not reached for a minimum of six days. In the non-responding group three achieved their best $\mathrm{FEV}_{1}$ on the first day, indicating if anything deterioration on steroids. The other three were at their best later in the study but the maximum 
T A B L E I I

\begin{tabular}{|c|c|c|c|c|c|c|}
\hline Patient & $\begin{array}{l}\text { Predicted } \\
\text { FEV }_{1} \\
\text { (litres) }\end{array}$ & $\begin{array}{c}\text { Baseline } \\
\text { FEV } \\
\text { (litres) }\end{array}$ & Predicted & $\begin{array}{l}\text { Best FEV }{ }^{*} \\
\text { achieved } \\
\text { (litres) }\end{array}$ & $\begin{array}{c}\% \\
\text { Predicted }\end{array}$ & $\begin{array}{l}\text { No. of Days } \\
\text { on Steroids } \\
\text { for Maximum } \\
\text { FEV }, \text { Response }\end{array}$ \\
\hline $\begin{array}{l}\text { AC } \\
\text { MB } \\
\text { BB } \\
\text { VM } \\
\text { MaB } \\
\text { MN } \\
\text { DW } \\
\text { JA } \\
\text { CC } \\
\text { FD } \\
\text { BH } \\
\text { DB }\end{array}$ & $\begin{array}{l}3 \cdot 1 \\
2 \cdot 3 \\
2 \cdot 1 \\
2 \cdot 4 \\
2 \cdot 4 \\
1 \cdot 9 \\
2 \cdot 5 \\
2 \cdot 8 \\
3 \cdot 4 \\
2 \cdot 1 \\
2 \cdot 1 \\
1 \cdot 9\end{array}$ & $\begin{array}{l}1.2 \\
1.15 \\
0.8 \\
0.65 \\
0.75 \\
1.1 \\
0.85 \\
0.6 \\
0.6 \\
0.4 \\
0.35 \\
0.5\end{array}$ & $\begin{array}{l}39 \\
50 \\
38 \\
27 \\
31 \\
58 \\
34 \\
21 \\
18 \\
19 \\
17 \\
26\end{array}$ & $\begin{array}{l}1.85 \\
2.0 \\
2.2 \\
1.85 \\
2.2 \\
2.85 \\
1.05 \\
0.7 \\
0.7 \\
0.55 \\
0.4 \\
0.7\end{array}$ & $\begin{array}{r}60 \\
87 \\
105 \\
77 \\
92 \\
150 \\
42 \\
25 \\
21 \\
26 \\
19 \\
37\end{array}$ & $\begin{array}{l}7 \\
7 \\
7 \\
7 \\
7 \\
6 \\
1 \\
7 \\
5 \\
2 \\
1 \\
1\end{array}$ \\
\hline
\end{tabular}

*Before isoprenaline.

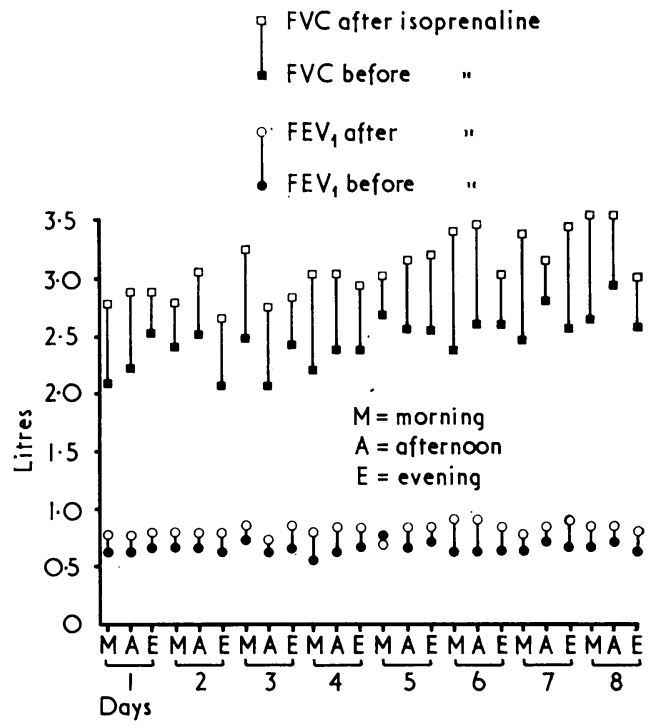

FIG. 1. Patient CC. Effect of prednisone treatment, as measured by forced vital capacity $(F V C)$ and forced expiratory volume in 1 second $\left(F E V_{1}\right)$ and the response to isoprenaline.

improvement in $\mathrm{FEV}_{1}$ whilst on steroids was only 0.15 litres (19-26\% predicted normal).

The remaining analysis of results was done with the first six patients who responded to prednisone, and the $\mathrm{FEV}_{1} 5$ minutes after isoprenaline was studied.

Figure 2 shows the $\mathrm{FEV}_{1}$ response in these six patients divided into three daily periods to eliminate the effects of diurnal variation. When plotted in this way all the patients showed some potentiation. This was very consistent with AC and $\mathrm{BB}$. With $\mathrm{MN}$ and $\mathrm{MB}$ the response varied, and with $\mathrm{MaB}$ potentiation was best seen in the evenings in the second half of the study, whereas with VM the best potentiation was seen in the
mornings.

For all these results only the best of the $5-\vec{\nabla}$ minute readings have been used. It seemed pos-sible that potentiation might also be expressed in $\frac{c}{\omega}$ a maintenance of improvement over 30 minutes or in a maintenance of the three 'blows'. There are two main patterns of serial $\mathrm{FEV}_{1}$ in patients withor airways obstruction: either their best blow is the first and the effort causes bronchospasm with deterioration following the next two blows, or the efforts clear secretions and the final blow ise the best. Each of the patients seemed to have his own pattern but corticosteroids in no way changed it. Thus in this respect there was no evidence of potentiation.

To obtain a numerical expression of the main tenance of improvement over the 30 minutes, results were expressed as:

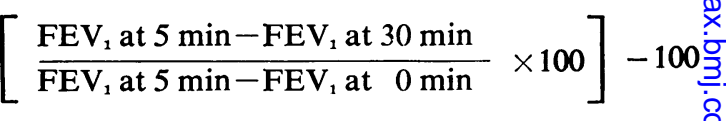

Thus $0 \%$ would indicate that at 30 minutes the measurements had fallen back to baseline valueso after the improvement at 5 minutes, and a high value indicates maintained improvement. Tableo III gives the mean results of the three percentages thus obtained for each day for all six patients. BB and VM clearly showed better maintenance of improvement after the baseline day. AC and MBN kept much the same pattern throughout but main $\sigma$ tained some of their improvement at 30 minutes even on their baseline day. MaB and MN did not improve at all overall on the baseline day, and? the results are erratic, so that there is onlyo definite evidence of potentiation in this respect5 in two patients, one of whom (VM) did not show potentiation as judged by an increased FEV response. 


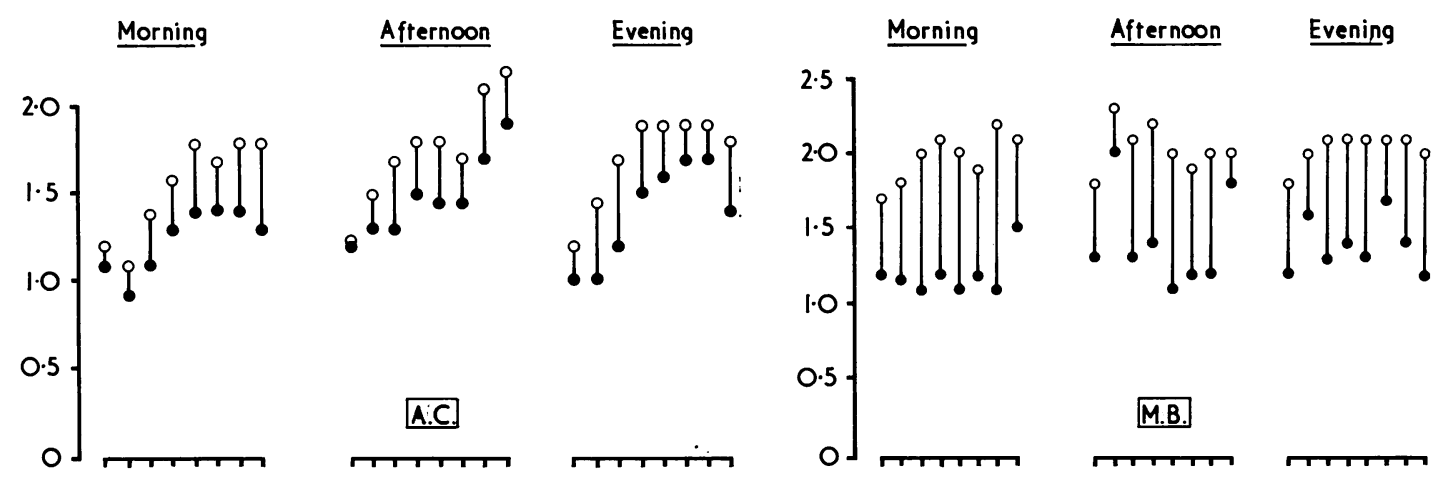

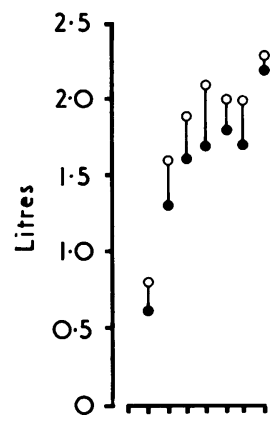
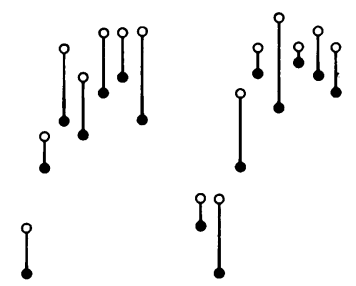

B.B.
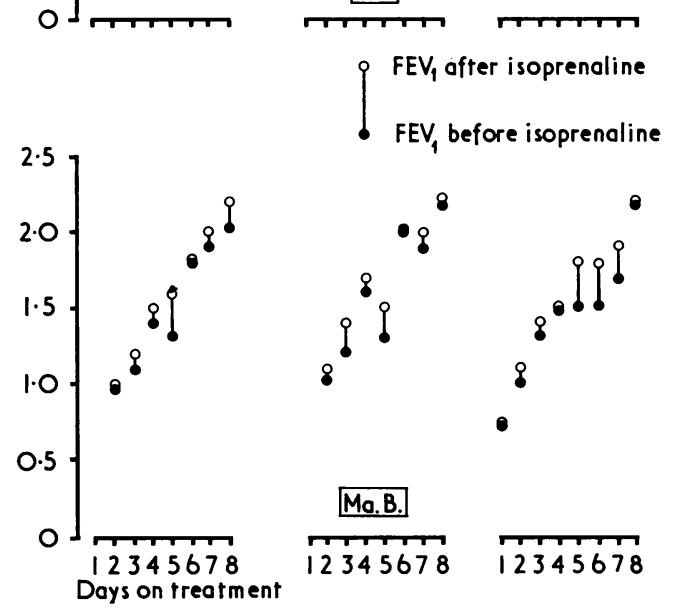

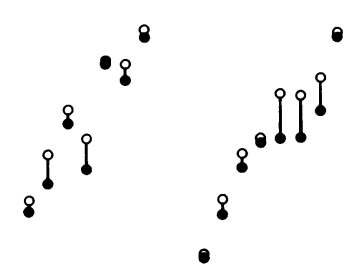

Mo.B.

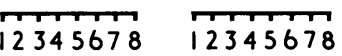

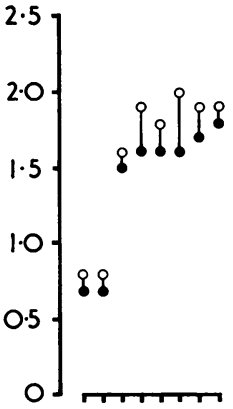
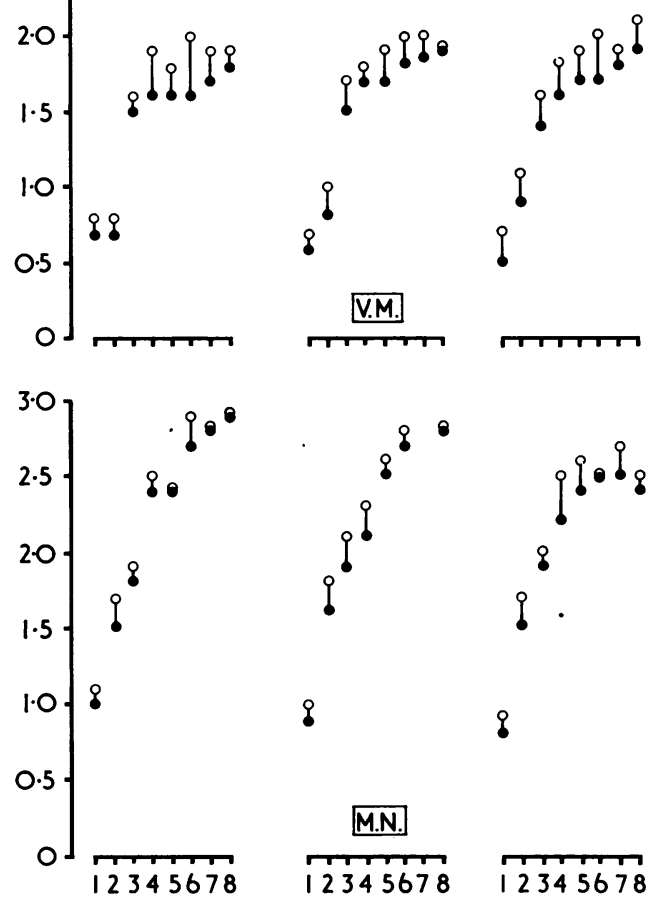

FIG. 2. Effect of prednisone treatment, as measured by forced expiratory volume in 1 second $\left(F E V_{1}\right)$ and the response to isoprenaline in six patients 'responding' to steroids.

These studies were not designed to find the time of onset of action of prednisone but some information was available. AC, MB, and VM all had a full day of baseline measurements and started their prednisone at 6 am the next morning. None had improved at 9 am but all showed a raised baseline $\mathrm{FEV}_{1}$ at lunchtime (6 hours from the onset). MN started her prednisone at $4 \mathrm{pm}$ on day 1 and $\mathrm{MaB}$ at $9 \mathrm{pm}$ on day 1 . Both had an improved baseline by the 9 am measurements the next day (17 and 12 hours respectively). BB started her prednisone at $6 \mathrm{pm}$ on the 'baseline' day but showed no improvement until 9 am, 36 hours later.

\section{DISCUSSION}

Of the nine patients with a clinical diagnosis of asthma, six showed a response to steroids. The 
T A B L E I I I

\begin{tabular}{|c|c|c|c|c|c|c|c|c|}
\hline \multirow[b]{2}{*}{ Patient } & \multirow[b]{2}{*}{ Baseline } & \multicolumn{7}{|c|}{ Day } \\
\hline & & 1 & 2 & 3 & 4 & 5 & 6 & 7 \\
\hline $\begin{array}{l}\text { AC } \\
\text { MB } \\
\text { BB } \\
\text { VM } \\
\text { MaB } \\
\text { MN }\end{array}$ & $\begin{array}{r}83 \\
64 \\
0 \\
0 \\
100 \\
100\end{array}$ & $\begin{array}{r}90 \\
60 \\
28 \\
58 \\
66 \\
-51\end{array}$ & $\begin{array}{r}90 \\
80 \\
5 \\
95 \\
0 \\
83\end{array}$ & $\begin{array}{r}95 \\
67 \\
93 \\
84 \\
-33 \\
47\end{array}$ & $\begin{array}{r}70 \\
71 \\
76 \\
97 \\
13 \\
-50\end{array}$ & $\begin{array}{l}86 \\
64 \\
81 \\
98 \\
83 \\
55\end{array}$ & $\begin{array}{r}69 \\
82 \\
59 \\
64 \\
-56 \\
75\end{array}$ & $\begin{array}{r}100 \\
28 \\
31 \\
100 \\
-33 \\
58\end{array}$ \\
\hline
\end{tabular}

$\left[\frac{\mathrm{FEV}_{1} \text { at } 5 \mathrm{~min}-\mathrm{FEV}_{1} \text { at } 30 \mathrm{~min}}{\mathrm{FEV}_{1} \text { at } 5 \mathrm{~min}-\mathrm{FEV}_{1} \text { at } 0 \mathrm{~min}} \times 100\right]-100$

patients who did not respond to steroids were older (mean 65; range 59 to 70 years) than those who did (mean 48 ; range 36 to 57 years), and five had chronic bronchitis.

Among the patients who did respond the time of first measurable improvement is interesting. Three patients had improved at 6 hours but not at 3 hours, and two between 0 and 17 hours or 0 and 12 hours. This differs from the findings of EllulMicallef, Borthwick, and McHardy (1972), who showed improvement one hour after administration of prednisone. Our finding of earliest response between 3 and 6 hours corresponds with that of Collins (personal communication) who found improvement at about 6 hours after giving intravenous hydrocortisone. One of our patients showed no response until 36 hours; thus any 'trial' of steroids should continue for a minimum of 36 to 48 hours. None of the responsive patients reached their best $\mathrm{FEV}_{1}$ until they had been on prednisone for six days, which would support the principle of a week's trial.

All of our steroid-responsive patients, while on prednisone, showed some potentiation of their response to isoprenaline, as defined by an increased increment in $\mathrm{FEV}_{1}$ and/or a maintenance of the improvement for 30 minutes. Interestingly, the patient who showed the latter phenomenon most convincingly had the least evidence of potentiation, as judged by an increased $\mathrm{FEV}_{1}$ response. We have shown that potentiation occurs but is not invariable. This is in keeping with the findings of Franklin et al. (1958). Kennedy (1961), Gregg (1969), and Lukas (1951) similarly showed potentiation in some patients although they did not discuss this particular finding. Bass (1972) claimed to find the opposite: less response to isoprenaline in patients on corticosteroids. Unfortunately his patients were on dexamethasone during their 'control' period, and neither the dose of dexamethasone nor of the subsequent ACTH or other steroid was stated.
Since potentiation can occur with isoprenalin $\overrightarrow{\overline{\vec{\omega}}}$ it presumably can also occur with endogenors catecholamines, and this may be one of the ways in which corticosteroids work in asthma. There is considerable evidence of the potentiating effee of corticosteroids. Mendelowitz, Gitlow, and Naftchi (1958) studied four patients with Cushing's syndrome and 13 patients on therapeutie corticosteroids and showed that their noradrenaline sensitivity was increased. Animal experiments have shown potentiation of catecholamines b $\frac{\vec{x}}{x}$ glucocorticoids in the isolated heart (Nasmyttw 1957), and in blood vessels (Fouler and Chou 1961; Altura, 1966). Kalsner (1969) showed that only sympathomimetic amines with the catechos nucleus were potentiated.

Kalsner (1969) also suggested that hydrocorti sone exerted its action by inhibiting catechol-O $\rightarrow$ methyl transferase, and it is known tha inhibitors of this enzyme also inhibit the uptak of catecholamines into smooth muscle (Gillespie 1973).

Exogenous catecholamines such as isoprenaline are partially inactivated by uptake into smoot muscle, and so inhibition of this process coule well potentiate catecholamine action.

Patients with asthma may, of course, respon well to corticosteroids without showing potentiå tion (that is, an increased peak or duration of response to isoprenaline). Aviado and Carrillo (1970) have reviewed the other possible mechanisms of corticosteroid action. These in clude direct smooth muscle relaxation on bronchos constricted rats and rabbits (Carrillo and Aviado? 1968; Aviado and Carrillo, 1969). Lefcoe (1956 also suggested that hydrocortisone had a direct action on the tracheal smooth muscle of guineapigs and cats, but Geddes and Lefcoe (1973£ thought that the action was probably due t $\bar{\alpha}$ preservatives in the solutions used. Fouler an 9 Chou (1961) and Altura (1966) found no direct action of corticosteroids in their preparations.

Other possible mechanisms are alteration of vascular permeability, anti-inflammatory, inhibition of antibody formation, and inhibition of histamine synthesis or storage: all have beew reviewed by Aviado and Carrillo (1970). Moder views of corticosteroid action include inductiom of protein synthesis (Feldman et al., 1972) whic है would perhaps explain immunological effects? Baxter and Forsham (1972) suggest that gluco corticoids bind to the cell nucleus, influencin o RNA synthesis. Such subcellular mechanism@ remain to be clarified, as do the interactions be tween catecholamines, corticosteroids, and 
cyclic AMP (Anderson, Bergh, and Svedmyr, 1972; Breckenridge, 1970).

In summary, we have shown that potentiation occurs between prednisone and isoprenaline in asthmatic patients. However, it is unlikely to be the sole mechanism of corticosteroid action.

GMS was supported by a grant from the Medical Research Council.

\section{REFERENCES}

Altura, B. M. (1966). Role of glucocorticoids in local regulation of blood flow. American Journal of Physiology, 211, 1393.

Andersson, R., Bergh, N. P., and Svedmyr, N. (1972). Metabolic actions in human bronchial muscle associated with ACTH induced relaxation. Scandinavian Journal of Respiratory Diseases, 53, 125.

Aviado, D. M., and Carrillo, L. R. (1969). Corticosteroids and their antiasthmatic action. Archives of Environmental Health, 18, 925.

Aviado, D. M. and Carrillo, L. R. (1970). Antiasthmatic action of corticosteroids: a review of the literature on their mechanism of action. Journal of Clinical Pharmacology, 10, 3.

Bass, H. (1972). Endogenous regulation of pulmonary response to isoproterenol. Chest, 61, 14 .

Baxter, J. D. and Forsham, P. H. (1972). Tissue effects of glucocorticoids. American Journal of Medicine, 53, 573.

Breckenridge, B. McL. (1970). Cyclic AMP and drug action. Annual Review of Pharmacology, 10, 19.

Carrillo, L. R. and Aviado, D. M. (1968). Mechanisms for the bronchodilator effects of corticosteroids in the sensitized rabbit. Journal of Pharmacology and Experimental Therapeutics, 164, 302.

Carryer, H. M., Koelsche, G. A., Prickman, L. E., Maytum, C. K., Lake, C. F. and Williams, H. L. (1950). Effects of cortisone on bronchial asthma and hay fever occurring in subjects sensitive to ragweed pollen. Proceedings of the Mayo Clinic, $25,482$.

Ellul-Micallef, R., Borthwick, R. C., and McHardy, G. J. R. (1972). Time course of response to corticosteroids in chronic bronchial asthma. Clinical Science, 43, 15P.

Feldman, D., Funder, J. W., and Edelman, I. S. (1972). Subcellular mechanisms in the action of adrenil steroids. American Journal of Medicine, 53, 545 .
Fouler, N. O., and Chou, N. H. F. (1961). Potentiation of smooth muscle contraction by adrenal steroids. Circulation Research, 9, 153.

Franklin, W., Michelson, A. L., Lowell, F. C., and Schiller, I. W. (1958). Bronchodilators and corticosteroids in the treatment of obstructive pulmonary emphysema. New England Journal of Medicine, 258, 774.

Freedman, S., and Prowse, K. (1966). How many blows make an FEV 1.0 ? Lancet, 2, 618.

Geddes, B. A. and Lefcoe, N. M. (1973). Respiratory smooth muscle relaxing effect of commercial steroid preparations. American Review of Respiratory Diseases, 107, 395.

Gillespie, J. S. (1973). Uptake of noradrenaline by smooth muscle. British Medical Bulletin, 29, 136.

Gregg, I. (1969). Reversibility of airways obstruction in asthma. Respiration, 26 (Suppl.), 123.

Kalsner, S. (1969). Mechanism of hydrocortisone potentiation of responses to epinephrine and norepinephrine in rabbit aorta. Circulation Research, 24, 383.

Kennedy, M. C. S. (1961). The assessment of bronchodilators. Proceedings of the Tuberculosis Research Council, 48, 81.

Lefcoe, N. M. (1956). The effect of hydrocortisone hemisuccinate on tracheal smooth muscle of the guinea-pig and cat. Journal of Allergy, 27, 352.

Lukas, D. S. (1951). Some effects of adrenocorticotropic hormone and cortisone on pulmonary function of patients with obstructive emphysema. American Review of Tuberculosis, 64, 279.

Mendelowitz, M., Gitlow, S., and Naftchi, N. (1958). Work of digital vasoconstriction produced by infused norepinephrine in Cushing's syndrome. Journal of Applied Physiology, 13, 252.

Nasmyth, P. A. (1957). The effect of corticosteroids on the isolated mammalian heart and its response to adrenaline. Journal of Physiology, 139, 323.

Pemberton, J. and Flanagan, E. G. (1956). Vital capacity and timed vital capacity in normal men over 40. Journal of Applied Physiology, 9, 291.

Schayer, R. W. (1964). A unified theory of glucocorticoid action. Perspectives in Biology and Medicine, 8, 71.

Requests for reprints to: Dr. J. W. Paterson, Cardiothoracic Institute, Fulham Road, Brompton, London SW3 6HP. 